УДК: $519.713: 517: 338$

Сергій Миколайович Чумаченко (доктор технічних наук, с.н.с) ${ }^{1}$

Рустам Камілович Мурасов (кандидат технічних наук, професор) ${ }^{2}$ Ярослав Вячеславович Мельник ${ }^{3}$

${ }^{1}$ Національний університет харчових технологій, Київ, Украӥна

${ }^{2}$ Головне управління оборонного планування Генерального штабу ЗСУ, Київ, Украӥна

${ }^{3}$ Національний університет оборони Украйни імені Івана Черняховського, Київ, Украйна

\title{
ТЕОРЕТИКО-МЕТОДОЛОГІЧНІ ОСНОВИ ІНФОРМАЦІЙНОГО АНАЛІЗУ ЕКОЛОГО-ТЕХНОГЕННИХ ЗАГРОЗ ДЛЯ ПОТЕНЦІЙНО- НЕБЕЗПЕЧНИХ ОБ'ЄКТІВ КРИТИЧНОЇ ІНФРАСТРУКТУРИ В УМОВАХ ЗБРОЙНОГО КОНФЛІКТУ НА СХОДІ УКРАЇНИ
}

В даній статті розглядаються питання розробки теоретико-методологічних основ інформачійного аналізу еколого-техногенних загроз для потенційно-небезпечних об'єктів критичної інфраструктури в умовах гібридної війни на сході України. Розглянуто потенційно небезпечні об'єкти критичної інфраструктури на сході України, які можуть стати джерелом чинників надзвичайної ситуачії воєнно-техногенного походження в разі можливого ураження боєприпасами під час ведення бойових дій. Це може призвести до виникнення ефекту доміно та втрат серед населення $і$ особового складу ЗС України та інших збройних формувань. Ланцюгова реакиія небезпечних наслідків може викликати екологічну катастрофу на Донбасі, яка за масштабами може перевищити рівні впливу застосування зброї масового ураження. Проведено інформачійний аналіз розтамування об'єктів критичної інфраструктури відносно лінії розмежування в зоні проведення операції об'єднаних Сил. Розроблено модель класифікації можливих загроз для об'єктів критичної інфраструктури.

Ключові слова: гібридна війна, об'єкти критичної інфраструктури, операції об'єднаних сил, екологічні катастрофи, оцінювання загроз.

\section{Вступ}

Розвиток сучасного воєнно-стратегічного тренду вже зараз призводить до розширення локальних і регіональних конфліктів, характерною рисою яких стала зміна форм вирішення міждержавних протиріч. Сьогоднішній зміст гібридних війн зводиться до "застосування непрямих асиметричних дій і способів їх ведення (“гібридних" війн), що дозволяє позбавити протиборчу сторону фактичного суверенітету без захоплення території держави військовою силою"[1]. Переможцем в такій війні стає держава або коаліція, що зуміли нав'язати супротивникові властиве їм бачення картини світу, цінностей, інтересів і що відповідає ї світогляду розуміння «справедливого» розподілу ресурсів.

Постановка проблеми. Разом зі збройною боротьбою, що становить специфічний зміст війни, в ній застосовуються також економічні, дипломатичні, науково-технічні, екологічні, інформаційні, ідеологічні, психологічні засоби і методи нав'язування супротивникові своєї волі, послаблення його військових можливостей i зміцнення власних позицій.

В той же час в сучасних умовах війна не обов'язково повинна асоціюватися 3 початком військових дій - продовження політики може здійснюватися насильницьким шляхом не лише військовими, але і невоєнними засобами. Наприклад здійсненням атак або виведенням 3 ладу потенційно-небезпечних об'єктів (систем) критичної інфраструктури, що примусить противника піти на поступки або нав'язати свої умови політики та економічної діяльності.

Аналіз останніх досліджень і публікацій. В ході досліджень було проведено аналіз наукових джерел вітчизняних i закордонних науковців, в яких розроблявся науково-методологічний апарат для оцінювання загроз для об'єктів критичної інфраструктури. Особливості оцінювання загроз для об'єктів критичної інфраструктури (ОКІ) під час гібридних війн досліджено лише частково і не в повному обсязі, про що свідчать публікації за цим напрямом таких вітчизняних науковців Биченка М.М., Яковлєва Є.О., Лисенка О.I., Кодріка А.І., Уряднікової І.В., Парталяна А.С., Туровець Ю.С., в роботах яких послідовно проводилась розробка категоріального апарату експертного оцінювання еколого-техногенних загроз для ОКІ [2, 3, 4, 5, 6, 7].

На основі вивчення досвіду країн-членів ЄС та НАТО з урахуванням безпекової ситуації в Україні Національним інститутом стратегічних досліджень розроблена "Зелена книга 3 питань захисту критичної інфраструктури" [8], шо встановлює чіткі особливості критичної інфраструктури, 
визначає основні цілі та принципи, за якими функціонує критична інфраструктура, як системна одиниця. В роботі Лядовської В.М., Гнатюка С.О., Рябого М.О. [9] проведено аналітичне дослідження нормативно-правової бази розвинених держав світу щодо варіацій ключових понять у галузі захисту критичної інфраструктури. Результати дозволили провести багатокритеріальний аналіз зазначених дефініцій i розробити методики віднесення тих чи інших об'єктів до критичної інфраструктури. В аналітичній доповіді Д.С. Бірюкова "Захист критичної інфраструктури: проблеми та перспективи впровадження в Україні" [10] висвітлюється необхідність формування єдиної державної політики у сфері захисту критично важливих об'єктів та інфраструктури в Україні. В науковій роботі В. Свсєєва [11] проведено аналіз досвіду захисту критичної інфраструктури в провідних країнах світу та наведено можливі шляхи вдосконалення захисту критичної інфраструктури України. В своїй статті [12] О. Суходоля провів дослідження пріоритетних напрямів та теоретико-методологічне обгрунтування визначення засад та принципів діяльності сектору безпеки у сфері захисту критичної інфраструктури. В своїй статті В. Чернета [13] комплексно розглянув систему критичної інфраструктури як невід'ємної підсистеми національної безпеки і встановив основні форм-фактори функціонування критичної інфраструктури. Стаття I. Уряднікової [14] висвітлює підходи до оцінювання ризиків і загроз на об'єктах критичної інфраструктури 3 використанням методом аналізу ієрархій. У роботі Бобро Д.Г. [15] проаналізовано сучасні методологічні підходи до оцінки критичності об'єктів інфраструктури та продемонстровано, що 3 урахуванням невизначеності, неточності та неповноти інформації, необхідної для коректної оцінки загроз та ризиків критичній інфраструктурі, багатовимірності можливих наслідків, необхідність урахування численних взаємозв'язків та взаємозалежностей об'єктів критичної інфраструктури, універсальність оцінки критичності може забезпечити застосування методів нечіткої логіки та експертних оцінок. Запропонована трирівнева ієрархічна модель критеріїв визначення критичності інфраструктури та надані пропозиції щодо подальших кроків із розбудови в Україні державної системи їі захисту. У матеріалах статті О.Лисенка [16] надається огляд найбільш поширених підходів щодо стратегій управління ризиками на об'єктах критичної інфраструктури. При виборі стратегії управління ризиками в умовах невизначеності пропонується використання різних критеріїв, які враховують цілісні установки, обмеження щодо умов його життєдіяльності та інших обставин. Надається аналіз критеріїв Вальда, Лапласа, Севіджа. У статті "Актуальні проблеми модернізації ризиків i загроз критичних інфраструктур"

Але в даних роботах методологія оцінки загроз для об'єктів критичної інфраструктури в зоні проведення операції об’єднаних сил не аналізувалась. 3 чого можна зробити висновок що тема дослідження оцінювання загроз для ОКІ в умовах гібридної війни не розкрита повністю i потребує подальшої розробки.

Метою статті $\epsilon$ обгрунтування критеріїв оцінювання та розробка теоретико-методологічних основ інформаційного аналізу екологотехногенних загроз для класифікації потенційнонебезпечних об'єктів критичної інфраструктури, що можуть стати цілями в у мовах гібридної війни сході України.

\section{Виклад основного матеріалу дослідження}

Розглянемо потенційно небезпечні об'єкти критичної інфраструктури на сході України, руйнування яких може призвести до катастрофічних наслідків (загибелі мирного населення, політичної та економічної дестабілізації, техногенних аварій і екологічних катастроф, евакуації населення та масової появи біженців). Масштаби збитків та наслідки в цьому випадку можна порівняти хіба що із наслідками від застосовування зброї масового ураження або тривалого ведення бойових дій на техногенно перевантаженій території.

Всіх цих наслідків противник в гібридній війні може легко досягти із залученням незначних сил $\mathrm{i}$ засобів, якщо своєчасно не будуть оцінені можливі загрози і своєчасно вжито відповідних заходів щодо забезпечення безпеки потенційно небезпечних об'єктів критичної інфраструктури [3].

Для проведення досліджень та оцінювання загроз розроблено модель класифікації та оцінювання загроз для ОКІ, основні елементи якої наведено на рис.1.

Першим етапом $є$ ідентифікація небезпек. Покажемо ii на прикладі Авдіївського коксохімічного заводу та його шламонакопичувачів на рис.2. Другий етап представляє собою експертний аналіз розвитку ситуації у випадку ураження шламонакопичувача та формування можливих сценаріїв [5], у яких розгорнуто послідовність розвитку техногенних аварій i екологічних катастроф при руйнуванні об'єктів критичної інфраструктури (рис.3, таб. 1).

Розглянемо детально зазначені об'єкти.

Хвостосховища на прикладі ПрАТ АКХЗ.

У шламонакопичувачі та хімнакопичувачі зберігається відповідно 6,5 млн тонн шламів вуглезбагачення (IV клас небезпеки відходів) та 443,1 тис. тонн хімічних відходів (II-IV класи небезпеки відходів) 16 станом на 2019 рік.

Відходи хімнакопичувача, нижній шар яких складають смолисті відходи, мають токсичні властивості та небезпечні для здоров'я людини. По суті це механічна суміш великої кількості органічних з'єднань, які можуть впливати на кровоносну систему, функції центральної та периферичної нервової системи, нирок та печінки. 


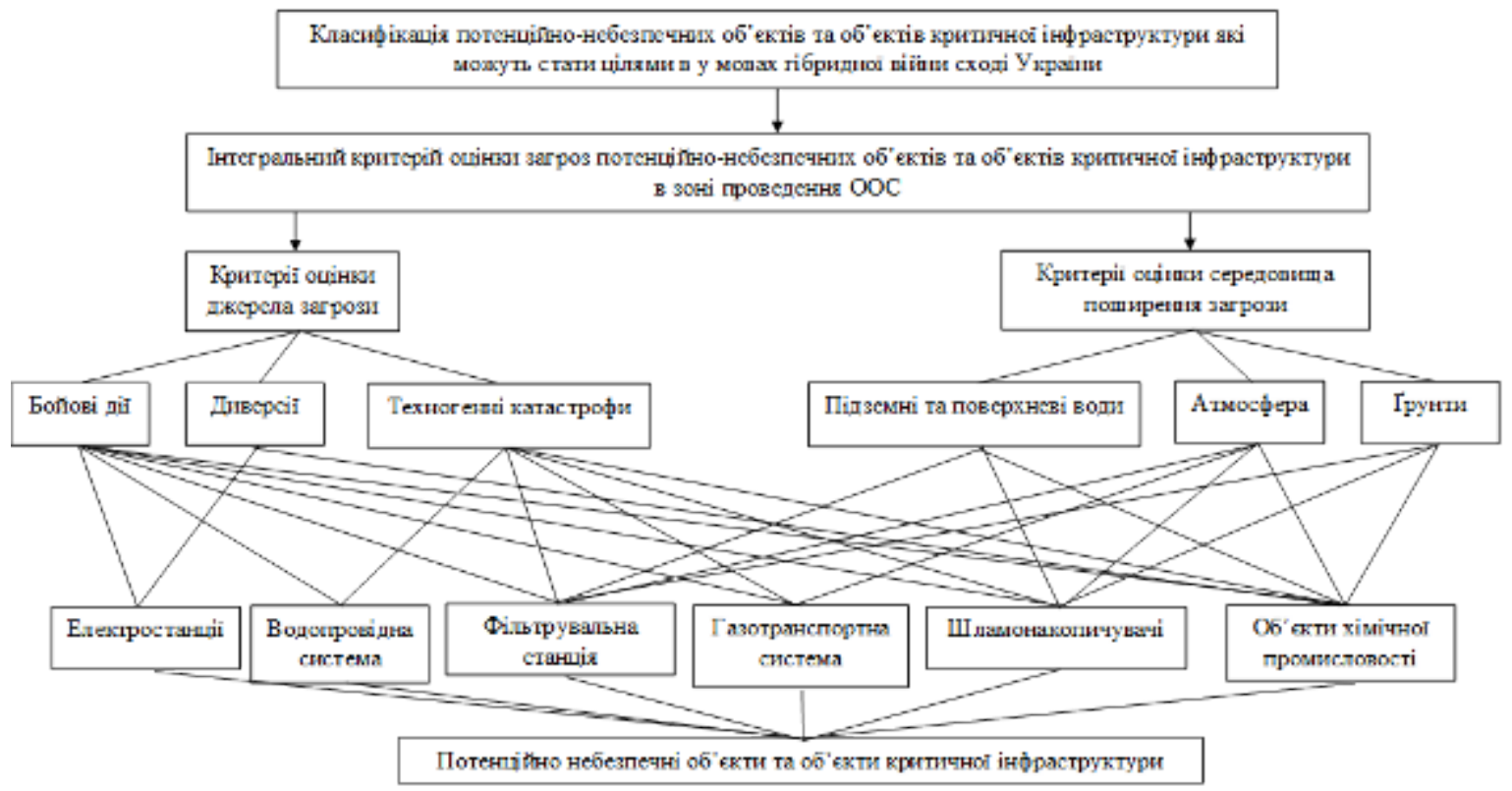

Рис.1 Модель класифікації та оцінки загроз об’єктів критичної інфраструктури

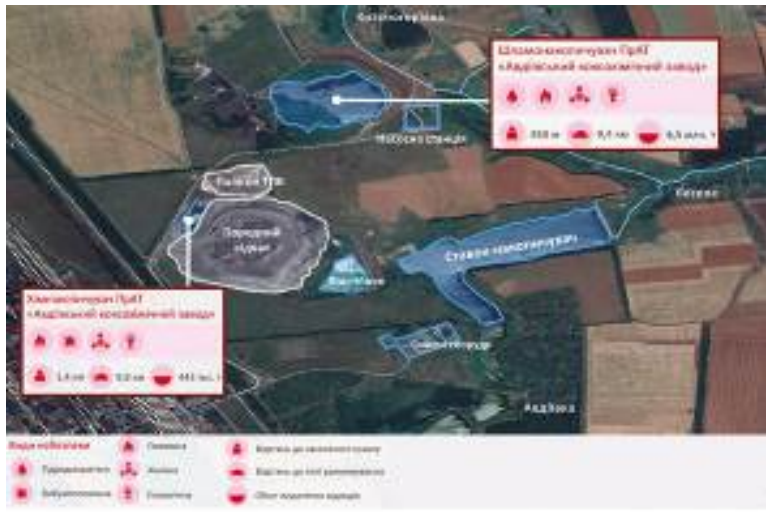

Рис. 2 Види небезпек від шламонакопичувачів ПрАТ АКХ3 [17]

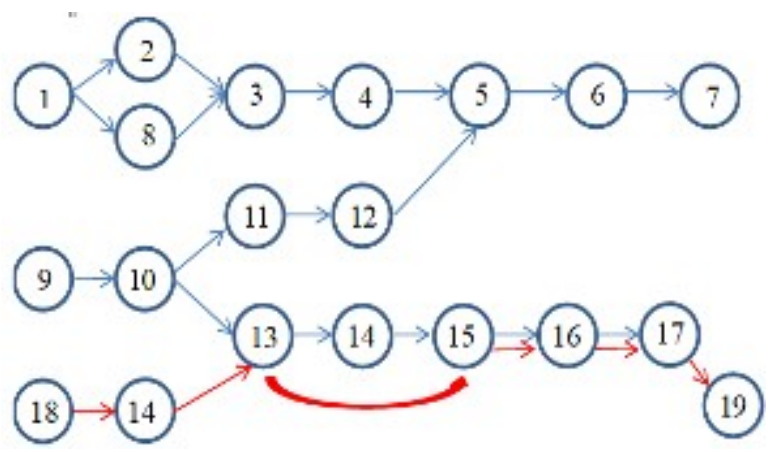

Рис.3 Послідовний розвиток екологічних катастроф при руйнуванні об'єктів критичної інфраструктури.

Таблиця 1

Значення розвитку екологічних катастроф при руйнуванні об'єктів критичної інфраструктури

\begin{tabular}{|l|l|}
\hline № & \multicolumn{1}{|c|}{ Опис події } \\
\hline 1 & Прорив дамби шламонакопичувача \\
\hline 2 & Затоплення села Красногорівка \\
\hline 3 & Загибель людей і сільських тварин \\
\hline 4 & $\begin{array}{l}\text { Забруднення значної території відходами із } \\
\text { шламонакопичувача }\end{array}$ \\
\hline
\end{tabular}

\begin{tabular}{|l|l|}
\hline$№$ & \multicolumn{1}{|c|}{ Опис події } \\
\hline 5 & $\begin{array}{l}\text { Забруднення річок Кам’янка й Очеретувата та } \\
\text { р. Кривий Торець }\end{array}$ \\
\hline 6 & Забруднення басейну річки Сіверський Донець \\
\hline 7 & $\begin{array}{l}\text { Транскордонне забруднення басейну нижнього } \\
\text { Дону }\end{array}$ \\
\hline 8 & Затоплення села Веселе \\
\hline 9 & Влучення снаряду в хімічний накопичувач \\
\hline 10 & Руйнування гідро бар'єру \\
\hline 11 & Вторинне забруднення грун. вод \\
\hline 12 & $\begin{array}{l}\text { Вторинне забруднення шламонакопичувача хім. } \\
\text { речовинами з хім. накопичувача }\end{array}$ \\
\hline 13 & Виникнення пожежі на хім. накопичувачі \\
\hline 14 & Виникнення пожежі на породному відвалі \\
\hline 15 & Забруднення приземного шару повітря \\
\hline 16 & $\begin{array}{l}\text { Задимлення прилеглої території (залізничного } \\
\text { полотна і полігону тв. побут. відходів) }\end{array}$ \\
\hline 17 & $\begin{array}{l}\text { Перекидання пожежі на прилеглу територію } \\
\text { (залізницю і полігон тв. побут. відходів) }\end{array}$ \\
\hline 18 & Влучення снаряду в породний відвал \\
\hline 19 & Перекидання пожежі на територію міста \\
\hline
\end{tabular}

Об'єкти хімічної промисловості.

На підконтрольній уряду України територій Донецької та Луганської областей знаходиться приблизно 150 об’єктів хімічної промисловості, які при застосуванні їх як цілі в гібридній війні несуть потенційну загрозу в залежності їх типу. На цих об'єктах знаходяться такі речовини як: хлор, аміак, фенол. Загальні обсяги отруйних речовин складають біля 10000 т.

Шахти.

3 початком ведення бойових дій на сході України, більшість шахт (близько 70 шахт) припинила свою діяльність, деякі шахти було затоплено [3]. Основна небезпека яку несуть шахти, це забруднення підземних вод токсичними речовинами, обвал пустот 3 подальшим руйнуванням прилеглих об'єктів, забруднення прилеглої території, забруднення річок та водосховищ, екологічна катастрофа районного

Modern Information Technologies in the Sphere of Security and Defence № 1(40)/2021 ISSSN2311-7249(Print)/ISSSN2410-7336(Onfine) 1119 
масштабу. В найближчій перспективі стан шахт буде наближуватись до небезпечного та критичного. Можлива поява техногенних землетрусів.

Об'єкти водопостачання.

Діючи об'єкти водопостачання не тільки забезпечують регіон водою але і містять хлор для очищення питної води. При руйнуванні крім припинення постачання питної води можливі жертви серед цивільного населення та довготривале забруднення території таб.2.

Перелік фільтрувальних станцій

та запаси хлору на них.

\begin{tabular}{|c|l|l|l|}
\hline $\begin{array}{l}\text { Фільтрувальна } \\
\text { станція }\end{array}$ & $\begin{array}{l}\text { Отруйні } \\
\text { речовини }\end{array}$ & $\begin{array}{l}\text { Відстань } \\
\text { від лініï } \\
\text { зіткнення }\end{array}$ & \\
\hline Донецька & Хлор 1т & 0 км & $\begin{array}{l}\text { смт. } \\
\text { Ясіновата }\end{array}$ \\
\hline $\begin{array}{l}\text { Маріупольській } \\
\text { міськводоканал }\end{array}$ & $\begin{array}{l}\text { Хлор } \\
9 \text { т }\end{array}$ & 20 км & $\begin{array}{l}\text { м. } \\
\text { Маріуполь }\end{array}$ \\
\hline Старокримська & $\begin{array}{l}\text { Хлор } \\
114 \text { т }\end{array}$ & 10 км & $\begin{array}{l}\text { м. } \\
\text { Маріуполь }\end{array}$ \\
\hline Красноармійська & $\begin{array}{l}\text { Хлор } \\
7 \text { т }\end{array}$ & 30 км & $\begin{array}{l}\text { смт. } \\
\text { Карлівка }\end{array}$ \\
\hline
\end{tabular}

Канал Сіверський Донець-Донбас являється єдиним джерелом питного водопостачання Донецької області. Пошкодження трубопроводів каналу СДД в районі насосної станції 3-го підйому (м. Горлівка) призведе до зупинки каналу, рис.4.

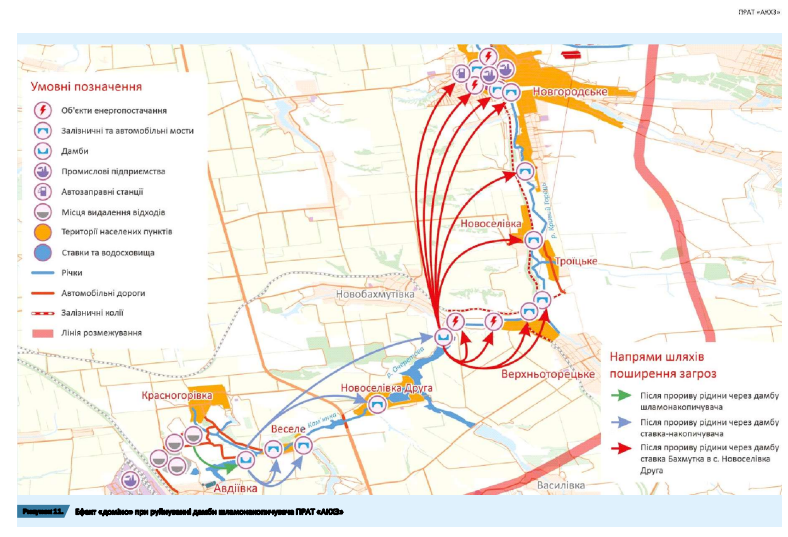

Рис. 4. Графічне представлення ефекту доміно [16]

При зупинці каналу СДД в зимовий період відбудеться руйнування льодового покриття, який 3 потоком руху води буде створювати крижані тороси, що призведуть до повного перекриття, як перерізу русла каналу, так і водозабірних споруд, а також при різкому зниженні рівня води в каналі призведе до зриву плит укосів, а також призведе до розморожування дюкерних переходів, виготовлених з сталевих труб великого перерізу. Відсутність водопостачання спричинить зупинку котелень і як наслідок розморожування систем опалення, тобто призведе до зриву теплопостачання міст і селищ Донецької області.

Зупинка каналу СДД у літній період призведе до спалаху інфекційних захворювань і створення несприялливої санітарно-епідеміологічної обстановки в містах і селищах Донецької області (понад 180 населених пунктів) із загальною чисельністю населення близько 2,6 млн. осіб (м. Горлівка, Снакієве, Макіівка, Донецьк, Покровськ, Докучаєвськ, Добропілля, Маріуполь та інші).

При зупинці каналу СДД фільтрувальні станції перейдуть на роботу з резервних джерел. ВеликоАнадольська фільтрувальна станція не має резервного джерела i без централізованого водопостачання залишиться населення загальною чисельністю близько 60 тис. чоловік. Вода 3 Карлівського водосховища, як резервного джерела Карлівської фільтрувальної станції, не буде відповідати вимогам СанПіН за деякими показниками.

Обсягів водосховищ-резервних джерел буде достатньо лише протягом 30 діб.

Об'єкти електрозабезпечення.

Об'єкти електрозабезпечення забезпечують електроенергією Луганську і Донецькі області у тому числі і окуповані території (таб. 3). Всі основні об'єкти знаходяться в безпосередній близькості 3 лінією зіткнення і можуть бути атаковані у будь який час (рис. 5,6$)$. Це призведе до енергетичної та гуманітарної катастроф.

Таблиця 3.

Перелік електростанцій які знаходяться в зоні ураження біля лінії зіткнення ООС.

\begin{tabular}{|c|c|c|}
\hline $\begin{array}{c}\text { Найменування } \\
\text { об'єкту }\end{array}$ & $\begin{array}{c}\text { Встановлена } \\
\text { електрична } \\
\text { потужність }\end{array}$ & $\begin{array}{c}\text { Відстань } \\
\text { від лінії } \\
\text { зіткнення }\end{array}$ \\
\hline $\begin{array}{c}\text { ДТЕК } \\
\text { ЛУГАНСЬКА } \\
\text { ТЕС }\end{array}$ & $1450 \mathrm{MBт}$ & 0,3 км \\
\hline Вуглегірська ТЕС & $3600 \mathrm{MBT}$ & 4,5 км \\
\hline $\begin{array}{c}\text { ДТЕК } \\
\text { КУРАХІВСЬКА } \\
\text { ТЕС }\end{array}$ & 1527 МВт & 21 км \\
\hline \multicolumn{2}{|c}{} & \\
\hline
\end{tabular}

Крім електростанцій об'єктами нападу у енергетичній сфері можуть бути електропідстанції та лінії електропередач. Подібні об'єкти під час війни в Югославії були першочерговими цілями авіації коаліції та призводили до гуманітарних катастроф регіонів, повністю паралізуючи економіку та повсякденне життя у містах.

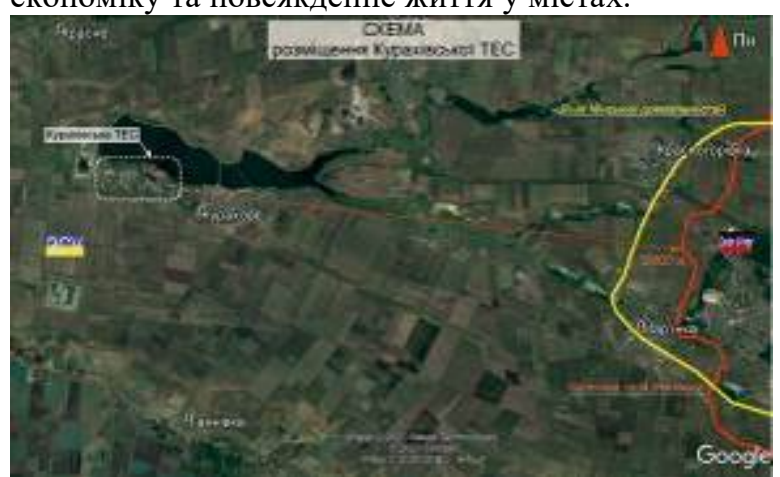

Рис.5 Схема розміщення Курахівської ТЕС. 


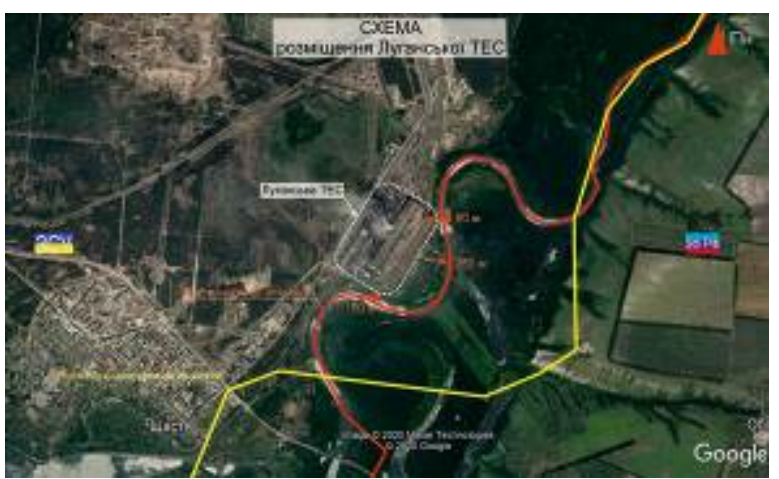

Рис.6. Схема розміщення Луганської ТЕС

У Донецькій області складають 32749 км, електропідстанції, 6892 підстанцій.

У Луганській області складають 16756 км, електропідстанції, 4122 підстанцій.

Газотранспортна система.

Атака на газотранспортну систему особливо в зимовий період спричинить гуманітарну катастрофу серед мирного населення і повністю паралізує роботу промисловості. Газотранспортна

\section{Лimepamypa}

1. Герасимов В.В. По опыту Сирии. Начальник Генерального штаба Валерий Герасимов: «Гибридная война требует высокотехнологичного оружия и научного обоснования» Военно-промышленный курьер 2016. https://www.vpk-news.ru/articles/29579. 2. Биченок М.М., Довгий С.О. Основи інформатизації управління регіональною безпекою. /- К.: Наук. думка, 2004. -287 с. 3. Кодрик А.І., Яковлєв С.О., Чумаченко С.М., Парталян А.С. Методичні підходи до геоінформаційного аналізу еколого-техногенних загроз для вуглепромислових районів Донбасу (на прикладі ПАО “Лисичанськвугілля" та ДП "Первомайськвугілля") // Математичне моделювання в економіці. Міжнародний науковий журнал. № 4 (13), жовтень-грудень 2018 р. С. 5-17. 4. Парталян А.С., Чумаченко С.М. Інформаційні технології в задачах управління екологічною безпекою військових об'єктів // Інформатика, обчислювальна техніка та автоматизація. Вчені записки Таврійського національного університету імені В.І. Вернадського. Том 29 (68) №1 2018 C.15-20. 5. Уряднікова I.B., Чумаченко С.M., Кармазін С.В. Застосування експертно-аналітичних методів для оцінювання ризиків надзвичайних ситуацій на об'єктах критичної інфраструктури - Науковий вісник Академії муніципального управління, 2015 С. 206-218. 6. Чумаченко С. М., Парталян А. С., Туровець Ю. С. Система підтримки прийняття рішень 3 управління екологічними загрозами у районі ведення бойових дій // 3б. наук. пр. № 1 (83). Київ: ЦНДІ ЗС України, 2018. С. 88-95. 7. Колечко В. М., Парталян А. С. Підхід до обгрунтування критеріїв оцінювання природнотехногенних загроз // Зб. наук. пр. № 2 (84). Київ: ЦНДІ 3С України, 2018. С. 233-240. 8. Упоряд. Д.С. Бірюков, система $\epsilon$ однією із вразливих енергетичних систем, на відновлення роботи якої необхідний тривалий період. Також атаки на газові сховища будуть мати катастрофічні наслідки. Наприклад пожежа на Васильківській нафтобазі де також зберігались продукти скрапленого газу. Внаслідок пожежі загинуло 6 осіб, а у Васильківському районі сталася екологічна катастрофа. Збитки від пожежі склали декілька мільйонів доларів. Витрати на гасіння пожежі оцінили у 50 мільйонів гривень.

\section{Висновки і перспективи подальших досліджень}

Таким чином в зоні проведення ООС визначено 6 основних видів потенційно-небезпечних об'єктів критичної інфраструктури які можуть бути цілями противника в гібридній війні. Руйнування даних об'єктів призведе до масових жертв серед цивільного населення України. Для визначення шляхів запобігання техногенних аварій i екологічної катастрофи та оптимального розподілу ресурсів для їх усунення виникає необхідність в науковому дослідженні рівнів загроз та створенні науково-методологічного апарату оцінки загроз i ризиків для потенційно-небезпечних об'єктів критичної інфраструктури в зоні проведення ООС.

С.І Кондратов за заг. ред. Суходолі О.М. Зелена книга 3 питань захисту критичної інфраструктури в Україні : зб. матеріалів міжнар. експерт. нарад . - К. : НІСД, 2016. - 176 с. 9. Лядовська В.М., Рябий М.О., Гнатюк С.О. Визначення критичної інформаційної інфраструктури та iї захист: аналіз підходів. Зв'язок. - 2014. - №4. - С. 3-7. 10. Бірюков Д.С Захист критичної інфраструктури: проблеми та перспективи впровадження в Україні : Аналітична записка. URL: http://www.niss.gov.ua/ articles/1026. 11. Свсєє В.О. Можливі шляхи удосконалення захисту критичної інфраструктури України 3 урахуванням світового досвіду. Збірник наукових праць Харківського національного університету Повітряних Сил. - 2016. - № 4(49). - С. 168-172. 12. Суходоля О.М. Захист критичної інфраструктури: Сучасні виклики та пріоритетні завдання сектору безпеки URL http://irbisnbuv.gov.ua/cgiin/irbis nbuv/nivanb 2017 1-2 7.pdf 13. Чернега В.М. Аналіз критичної інфраструктури та напрямки досліджень систем життєзабезпечення об'єктів України : Аналітична записка. http://pm.khpi.edu.ua/article/download/2413-3000.2019.

1327.9/162867. 14. Бобро Д.Г. Методологія оцінки рівня в критичній інфраструктурі / Д.Г. Бобро // Стратегічні пріоритети. - Серія «Економіка». - 2015. - № 4 (37). - С. 83-93. 15. Лисенко О.І., Чеканова І.В., Кутовий О.П., Нікітін В.А.. Стратегії управління ризиками на об'єктах критичної інфраструктури в умовах невизначеності [Електронний ресурс] / O.I. Лисенко. - URL http://www.niss.gov.ua/content/articles/files/infrastrukt-

86de2.pdf. 16. Хвостосховища Донбасу. Звіт по проекту ОБСЄ. 2019. - 50 c. https://www.osce.org/uk/projectcoordinator-in-ukraine/456847 


\title{
ТЕОРЕТИКО-МЕТОДОЛОГИЧЕСКИЕ ОСНОВЫ ИНФОРМАЦИОННОГО АНАЛИЗА ЭКОЛОГО- ТЕХНОГЕННЫХ УГРОЗ ДЛЯ ПОТЕНЦИАЛЬНО ОПАСНЫХ ОБЪЕКТОВ КРИТИЧЕСКОЙ ИНФРАСТРУКТУРЫ В УСЛОВИЯХ ВООРУЖЕННОГО КОНФЛИКТА НА ВОСТОКЕ УКРАИНЫ
}

\author{
Сергей Николаевич Чумаченко (доктор технических наук, с.н.с) ${ }^{1}$ \\ Рустам Камілович Мурасов (кандидат технических наук) \\ Ярослав Вячеславович Мельник ${ }^{3}$
}

\author{
${ }^{1}$ Национальный университет харчевых технологий, Киев, Украина \\ ${ }^{2}$ Гланое управление оборонного планирования Генерального штабу ЗСУ, Киев, Украина \\ ${ }^{3}$ Национальный университет обороны Украины имени Ивана Черняховского, Киев, Украина
}

В данной статье рассматриваются вопросы разработки теоретико-методологических основ информационного анализа эколого-техногенных угроз для потенциально опасных объектов критической инфраструктуры в условиях гибридной войны на востоке Украины. Рассмотрены потенциально опасные объекты критической инфраструктуры на востоке Украины, которые могут стать источником факторов чрезвычайной ситуации военно-техногенного происхождения в случае возможного поражения боеприпасами во время ведения боевых действий. Это может привести к возникновению эффекта домино и потерь среди населения и личного состава ВС Украинь и других вооруженных формирований. Цепная реакция опасных последствий может вызвать экологическую катастрофу в Донбассе, которая по масштабам может превысить уровни воздействия применения оружия массового поражения. Проведен информаџионный анализ расположения объектов критической инфраструктуры относительно линии разграничения в зоне проведения операчии объединенных сил. Разработана модель классификации возможных угроз для объектов критической инфраструктуры.

Ключевые слова: гибридная война, объектьл критической инфраструктуры, операции объединенных сил, экологические катастрофы, оиенка угроз.

\section{THEORETICAL AND METHODOLOGICAL BASIS OF INFORMATION ANALYSIS OF ECOLOGICAL AND MAN-GENERAL THREATS FOR POTENTIALLY HAZARDOUS FACILITIES OF CRITICAL INFRASTRUCTURE IN THE CONDITIONS OF THE ARMED CONFLICT IN THE EAST OF UKRAINE}

\author{
Serhii Chumachenko (Doctor of technical sciences, Senior Research Fellow) ${ }^{1}$ \\ Rustam Murasov (Candidate of technical sciences) ${ }^{2}$ \\ Yaroslav Melnyk ${ }^{3}$,
}

${ }^{1}$ National university of food technologies, Kyiv, Ukraine

${ }^{2}$ State Main Directorate of Defense Planning of the General Staff of the Armed Forces of Ukraine, Kyiv, Ukraine

${ }^{3}$ National Defence University of Ukraine named after Ivan Cherniakhovsky, Kyiv, Ukraine

This article discusses the development of theoretical and methodological foundations of information analysis of environmental and technogenic threats to potentially dangerous critical infrastructure facilities in the context of a hybrid war in eastern Ukraine. Potentially dangerous objects of critical infrastructure in the east of Ukraine, which can become a source of factors of an emergency of military-technological origin in the event of a possible defeat by ammunition during the conduct of hostilities, are considered. This can lead to the emergence of a domino effect and losses among the population and personnel of the Armed Forces of Ukraine and other ARMED formations. A chain reaction of dangerous consequences can cause an ecological catastrophe in Donbass, which in scale may exceed the levels of impact of the use of weapons of mass destruction. An informational analysis of the location of critical infrastructure facilities relative to the demarcation line in the zone of the joint forces operation was carried out. A model has been developed for the classification of possible threats to critical infrastructure facilities.

Key words: hybrid war, critical infrastructure facilities, joint force operations, environmental disasters, threat assessment. 